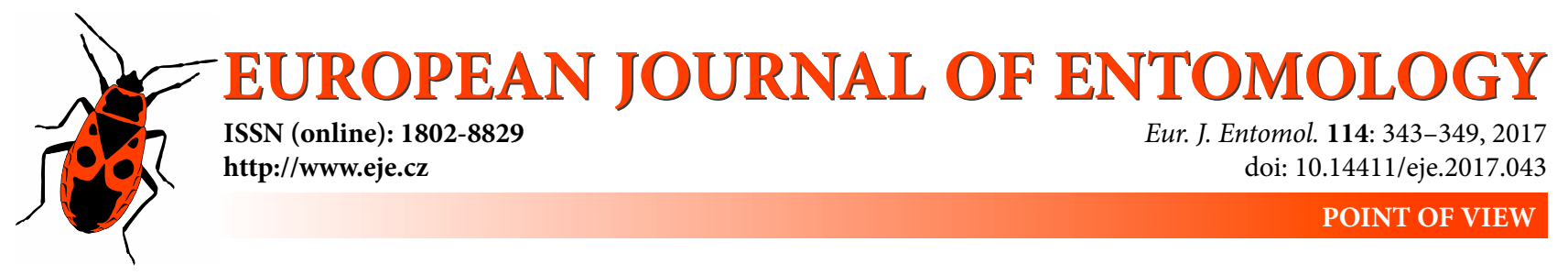

\title{
White plant shoots, wax-producing insects and other white structures made by arthropods: A mimicry complex?
}

\author{
KAZUO YAMAZAKI \\ Osaka Institute of Public Health, 8-34 Tojo-cho, Tennoji, Osaka 543-0026, Japan; e-mail: kazuo-yamazaki@iph.osaka. jp
}

Key words. Plant mimicry, anti-herbivore defence, cocoon, entomopathogenic fungus, spider egg sac, spittlebug froth, trichome, wax

\begin{abstract}
Many insects masquerade as parts of plants, such as bark or leaves, or mimic poisonous organisms in order to defend themselves against predators. However, recent studies indicate that plants may mimic insects and other arthropods to deter herbivores. Here, I report visually similar white structures of plants and arthropods in Japan and suggest they are part of a mimicry complex. Young shoots covered with white trichomes or waxy substances may mimic wax-producing insects, such as woolly aphids, coccids and caterpillars, potentially resulting in reduced herbivory. Since wax-producing insects would reduce plant quality and quantity, be distasteful and attract natural enemies, herbivorous insects and mammals may avoid such white shoots. Furthermore, fungus-infected insects, gregarious braconid cocoons, spider egg sacs and froth made by froghopper nymphs or blasticotomid sawfly larvae are also conspicuously white and impose risks for herbivorous insects. Thus, these white structures may be mimicry models for white shoots and are likely to be part of a defensive mimicry complex. Although this study focuses on defence against herbivores, there are simultaneous physiological roles for white colouration that will not be discussed in depth here.
\end{abstract}

\section{INTRODUCTION}

Many insects visually masquerade as inedible or inanimate objects, including plant parts (e.g. bark, twigs and leaves), stones and faeces, in order to hinder detection or decrease perception efficiency of predators (e.g. Cott, 1940; Edmunds, 1974; Skelhorn et al., 2010; Suzuki \& Sakurai, 2015), while others mimic poisonous or dangerous model organisms to deter predation (e.g. Wickler, 1968; Ruxton et al., 2004; Howse, 2014; Polidori et al., 2014). A masquerade can be defined as camouflage without crypsis, in which predators misidentify prey animals as inedible objects resulting in the survival of the prey (Skelhorn et al., 2010; Skelhorn, 2015). Defensive (Batesian) mimicry is a strategy by which prey animals mimic conspicuous dangerous animals (models) in order to protect themselves from predators (signal receivers) (Ruxton et al., 2004; Allaby, 2010). In Müllerian mimicry, aposematic dangerous species share a similar appearance enhancing efficient avoidance by predators (Ruxton et al., 2004; Allaby, 2010).

Conversely, it is becoming recognised that plants often visually mimic arthropods to decrease herbivory (Lev-Yadun \& Inbar, 2002; Lev-Yadun, 2016, 2017, and citations therein). In such defensive mimicry by plants, plants are mimics, arthropods models and herbivores the putative signal receivers (Lev-Yadun \& Inbar, 2002; Lev-Yadun, 2016, 2017). For instance, tiny structures that resemble butterfly eggs on Passiflora plants prevent oviposition by Helico- nius butterflies (Williams \& Gilbert, 1981). Leaf variegation in Caladium (Araceae) plants reduces herbivory by visually mimicking previous attacks by leaf miners (Soltau et al., 2009). Several studies have also proposed defensive plant mimicry of other arthropods or their action, for instance aphids, ants, caterpillars, bees, wasps and beetles, and of remains or structures produced by arthropods, such as silk, leaf damage and plant galls (Niemelä \& Tuomi, 1987; Lev-Yadun \& Inbar, 2002; Lev-Yadun \& Ne'eman, 2012; Polte \& Reinhold, 2013; Yamazaki \& Lev-Yadun, 2014, 2015; Lev-Yadun, 2016, 2017). Mimicry of arthropods or arthropod-made structures by plants is expected to reduce herbivory, as herbivores often avoid plants showing arthropod activity because of (1) food shortage due to consumption by other herbivores (Hilker \& Meiners, 2011), (2) deterioration of food quality caused by induced plant defences (Karban \& Baldwin, 1997; Kessler \& Baldwin, 2001; Karban, 2015), (3) threat of poisonous or aggressive arthropods, such as ants, bees, wasps, distasteful insects and spiders (Lev-Yadun \& Inbar, 2002; Lev-Yadun \& Ne'eman, 2012; Yamazaki \& Lev-Yadun, 2014, 2015; Lev-Yadun, 2016, 2017), and (4) attraction of natural enemies to apparent herbivorous arthropods (Niemelä \& Tuomi, 1987; Kessler \& Baldwin, 2001).

Visual mimicry of arthropods or their structures by plants is attained primarily by pigments (e.g. anthocyanin, betalain) and occasionally by trichomes and internal, 
subepidermal air spaces (e.g. leaf mottling) (Lev-Yadun, 2006a, 2014a, 2016; Yamazaki \& Lev-Yadun, 2015). Thus, plants most often use red, brown, black and white patterns to mimic arthropods (Lev-Yadun, 2006a, 2016, 2017). Red, brown and black spots and markings on plants may mimic various arthropods, including ants, aphids, aposematic caterpillars and leaf beetles (Lev-Yadun \& Inbar, 2002; Yamazaki \& Lev-Yadun, 2014; Lev-Yadun, 2016, 2017). White is also employed in several putative instances of plant mimicry. For instance, masses of white thread-like trichomes are proposed to mimic silk produced by spiders, caterpillars and mites (Yamazaki \& Lev-Yadun, 2015). Moreover, white leaf variegation may mimic scale insects, leaf mines, fungal hyphae or bird droppings, leading to reduced herbivory (Lev-Yadun, 2016; Lev-Yadun \& Niemelä, 2017).

White surfaces scatter-reflect all spectra of visible light. Because white is striking against dark backgrounds, such as soil, bark, or foliage, many animals use white patterns for communication among conspecifics or with other animals. White colouration is also useful for thermoregulation, and may provide camouflage in snowy or icy environments or in deserts with light-coloured sand (e.g. CloudsleyThompson, 1979; Caro, 2005, 2009; Lev-Yadun, 2016). In insects, various taxa produce white waxes that are mixtures of long-chain esters, straight-chain hydrocarbons and free fatty acids (Brown, 1975) as a defence against natural enemies, UV radiation and desiccation (Pope, 1979, 1983; Eisner et al., 2005; Yamazaki, 2012). On the other hand, plants use white colouration primarily to attract pollinators, although most white flowers have at least some dark parts when viewed under UV radiation, which usually serve the pollinating insects as nectar guides (Eisner et al., 1969; Tanaka, 1982). In addition, the vegetative parts of many plants have white patterns caused by trichomes, waxy substances and various mechanisms that cause visual variegation (Lee, 2007; Lev-Yadun, 2014a). These whitish parts have physiological functions such as increasing UV reflection and desiccation tolerance (Lee, 2007), but may also play a role in visual mimicry (Lev-Yadun, 2014a, 2016).

Here, I discuss white plant structures occurring in Japan that have the potential to visually mimic wax-producing insects, and propose a possible white mimicry complex involving plants and insects.

\section{STUDY SITES AND METHODS}

I searched for possible instances of defensive animal mimicry by plants as a pilot study in Japan from March to November in 2010 to 2016 . Various types of plants, including herbaceous plants, climbers, shrubs and trees, were carefully examined in urban parks, botanical gardens, arable lands, along riverbanks and in forests in Osaka, Kyoto, Nara, Hyogo, Wakayama, and Yamanashi Prefectures in central Japan. Primary study sites were Tsurumi-ryokuchi Park $\left(34^{\circ} 42^{\prime} \mathrm{N}, 135^{\circ} 34^{\prime} \mathrm{E}, 4 \mathrm{~m}\right.$ above sea level), Osaka Castle Park (34⒋ $41^{\prime}$ E, $135^{\circ} 31^{\prime}$ E, 30 m a.s.l.), Nagai Botanical Garden $\left(34^{\circ} 36^{\prime} \mathrm{N}, 135^{\circ} 31^{\prime} \mathrm{E}, 9 \mathrm{~m}\right.$ a.s.1.), Kyoto Botani- cal Garden $\left(35^{\circ} 3^{\prime} \mathrm{N}, 135^{\circ} 46^{\prime} \mathrm{E}, 70 \mathrm{~m}\right.$ a.s.l.), Yamato River $\left(34^{\circ} 35^{\prime} \mathrm{N}, 135^{\circ} 30^{\prime} \mathrm{E}, 7 \mathrm{~m}\right.$ a.s.l.), Yodo River $\left(34^{\circ} 53^{\prime} \mathrm{N}\right.$, $135^{\circ} 42^{\prime} \mathrm{E}, 11 \mathrm{~m}$ a.s.1.), Mt. Ikoma $\left(34^{\circ} 40^{\prime} \mathrm{N}, 135^{\circ} 39^{\prime} \mathrm{E}\right.$, 150-640 m a.s.1.), Mt. Minoo (34 $51^{\prime} \mathrm{N}, 135^{\circ} 28^{\prime} \mathrm{E}, 80-380$ $\mathrm{m}$ a.s.1.), and Enzan $\left(35^{\circ} 42^{\prime} \mathrm{N}, 138^{\circ} 49^{\prime} \mathrm{E}, 1250-1550 \mathrm{~m}\right.$ a.s.l.). Then, I noted plant structures that visually resembled wax-producing insects, real wax-producing insects, and other white structures made by arthropods and plants.

\section{OBSERVATIONS}

\section{White plant shoots}

The terminal parts of young shoots, including the buds, stems, and young leaves of some herbaceous plants, shrubs and trees, were visually similar to the human eye to colonies of wax-producing insects (Table 1a). These were caused by a dense covering of white trichomes on the stems of Artemisia indica Willd. var. maximowiczii (Nakai) $\mathrm{H}$. Hara (Asteraceae) (Fig. 1a), Achyranthes bidentata Blume var. faurieri (H. Lév. et Vaniot) (Amaranthaceae) (Fig. 1b), Macleaya cordata (Willd.) R. Br. (Papaveraceae) (Fig. 1c), Lespedeza thunbergii Nakai (Fabaceae), Rubus phoenicolasius Maxim. (Rosaceae) (Fig. 1d) and Clerodendrum trichotomum Thunb. (Lamiaceae) (Fig. 1e), or by whitish waxy substances on buds and young leaves of Chenopodium album L. (Amaranthaceae) (Fig. 1f) and Melia azedarach L. (Meliaceae) (Fig. 1g). Peduncles of Sonchus oleraceus L. (Asteraceae) (Fig. 1h) are covered with white wax, which resembles woolly aphid colonies. Most of these white structures are abundant in spring and early summer (from March to June on A. indica var. maximowiczii, M. cordata, R. phoenicolasius, C. trichotomum, M. azedarach, $S$. oleraceus), but are also found in mid summer and autumn (July to November on A. bidentata var. faurieri, L. thunbergii, C. album). Although A. bidentata var. faurieri and $M$. azedarach are restricted to grasslands and forest edges in the lowlands and $R$. phoenicolasius grew only in mountainous regions, other species are found commonly from lowlands to montane areas. There is variation in the density of white trichomes and amount of wax on individual plants, and mature shoots mainly lack trichomes and wax.

\section{Wax-producing insects on plants}

During field observations, I also found and noted diverse wax-producing insects, including woolly aphids [e.g. Shivaphis celti Das (Fig. 2a), Colopha kansugei (Uye), and Colophina clematis (Shinji)], scale insects [e.g. Orthezia yasushii Kuwana, Takahashia japonica (Cockerell) and Ceroplastes ceriferus (Fabricius)], flatid nymphs [Geisha distinctissima (Walker)] (Fig. 2b), nymphs of jumping plant lice (e.g. Anomoneura mori Schwarz, Psylla morimotoi Miyatake) (Fig. 2c), delphacid nymphs [Saccharosydne procerus (Matsumura)], sawfly larvae (Eriocampa mitsukurii Rohwer, E. kurumivora Togashi), lepidopteran caterpillars [e.g. Epicopeia hainesii hainesii Holland (Fig. 2d), Psychostrophia melanargia Butler, Epipomponia nawai (Dyar), and Samia cynthia pryeri (Butler)], and ladybird larvae (Scymnus Kugelann, Hyperaspis Redten- 
Table 1. White structures on plants and of arthropods recorded in central Japan.

\begin{tabular}{|c|c|c|c|}
\hline White structures on plants and of arthropods & Habitat $^{1}$ & Season $^{2}$ & Morphology ${ }^{3}$ \\
\hline \multicolumn{4}{|l|}{ a) White plant shoots } \\
\hline Artemisia indica var. maximowiczii & L, LM, M & SP & Cylindrical, Sheet like \\
\hline Achyranthes bidentata var. faurieri & $\mathrm{L}$ & SU, AU & Cylindrical, Sheet like \\
\hline Macleaya cordata & LM, M & SP, SM & Sheet like \\
\hline Lespedeza thunbergii & L, LM, M & SU, AU & Sheet like \\
\hline Rubus phoenicolasius & $\mathrm{M}$ & SP, SU & Cylindrical, Sheet like \\
\hline Clerodendrum trichotomum & L, LM, M & SP & Cylindrical, Sheet like \\
\hline Chenopodium album & L, LM & SU, AU & Sheet like \\
\hline Melia azedarach & $\mathrm{L}$ & SP & Cylindrical, Sheet like \\
\hline Sonchus oleraceus & L, LM & SP & Cylindrical, Patchy \\
\hline \multicolumn{4}{|l|}{ b) Wax-producing insects } \\
\hline Woolly aphids & L, LM, M & SP, AU & Cylindrical, Sheet like \\
\hline Coccoidea & L, LM & SP, SU, AU & Cylindrical, Sheet like \\
\hline Flatid nymphs & L, LM, M & SP, SU & Cylindrical \\
\hline Psyllid nymphs & L, LM, M & $\mathrm{SP}$ & Sheet like \\
\hline Delphacid nymphs & $\mathrm{L}$ & SP, SU & Patchy \\
\hline Tenthredinid larvae & L, LM, M & $\mathrm{SP}$ & Cylindrical \\
\hline Lepidopteran caterpillars & L, LM, M & SP, AU & Cylindrical \\
\hline Coccinellid larvae & L, LM & SP & Patchy \\
\hline \multicolumn{4}{|l|}{ c) Other white structures of arthropods } \\
\hline Fungus-infected insects & LM, M & SU, AU & Cylindrical, Patchy \\
\hline Braconid cocoons & L, LM & SP, SU, AU & Cylindrical \\
\hline Spider egg sacs and webs & L, LM, M & SP, SU, AU & Patchy, Sheet like \\
\hline Cercopoidea froth & L, LM, M & SP & Cylindrical, Patchy \\
\hline Blasticotomid froth & LM & SU, AU & Patchy \\
\hline Rhopalomyia giraldii galls & L, LM, M & SP, SU, AU & Patchy \\
\hline \multicolumn{4}{|l|}{ d) Other white structures on plants } \\
\hline Asteraceous pappi & L, LM, M & SP & Patchy \\
\hline Salicaceous comae & L, LM, M & SP & Cylindrical \\
\hline
\end{tabular}

${ }^{1} \mathrm{~L}-$ lowlands (<100 $\mathrm{m}$ above sea level), LM - low mountains and hills (100-1000 m a.s.I.), M - mountains (>1000 m a.s.I.); ${ }^{2}$ SP- spring (March-May), SU - summer (June-August), AU - autumn (September-November); ${ }^{3}$ Sheet like white structures are primarily found on the underside of leaves.
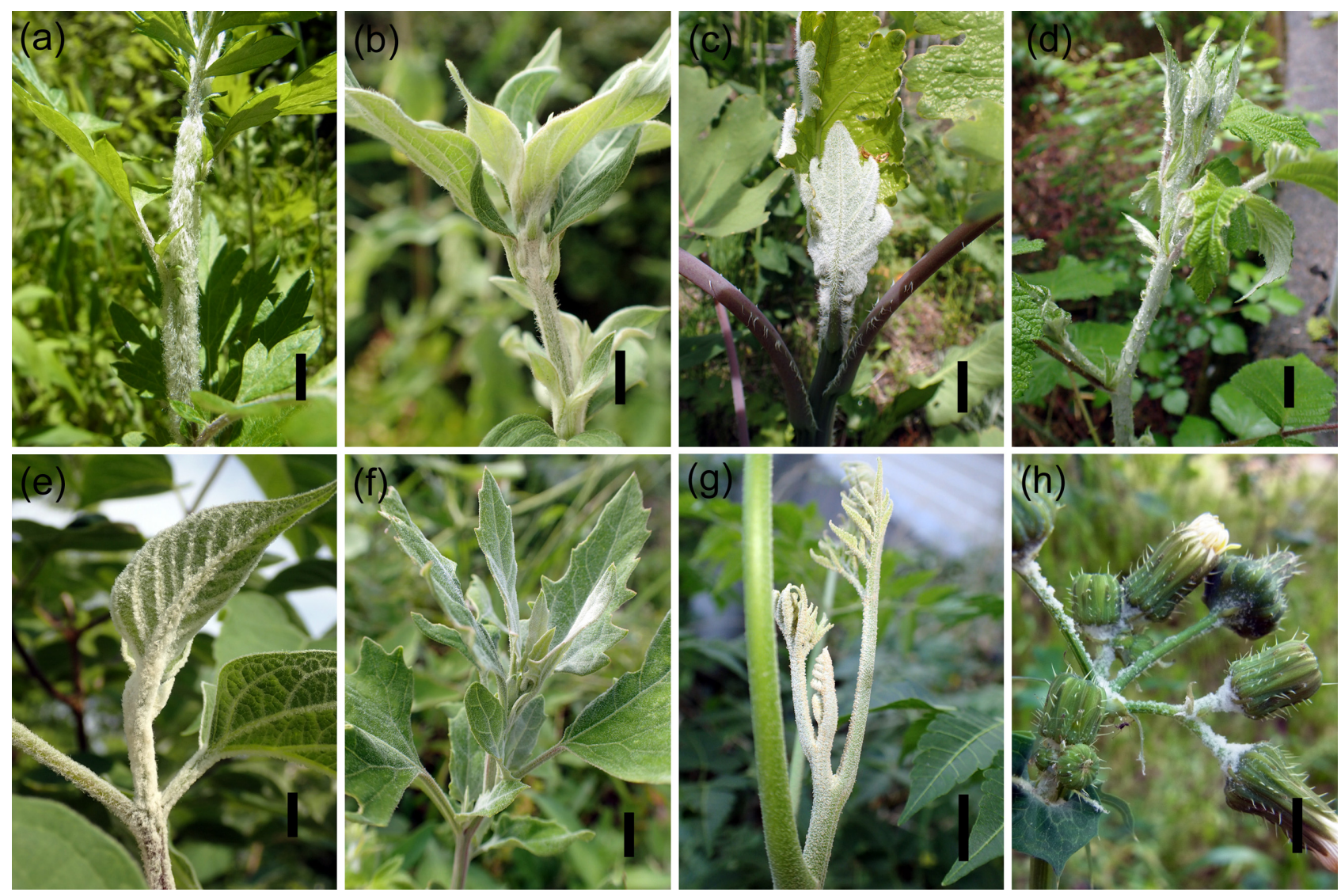

Fig. 1. Young shoots bearing white trichomes and waxy substances. (a) Artemisia indica var. maximowiczii, (b) Achyranthes bidentata var. faurieri, (c) Macleaya cordata, (d) Rubus phoenicolasius, (e) Clerodendrum trichotomum, (f) Chenopodium album, (g) Melia azedarach, (h) Sonchus oleraceus. Scale bars: $10 \mathrm{~mm}$. 

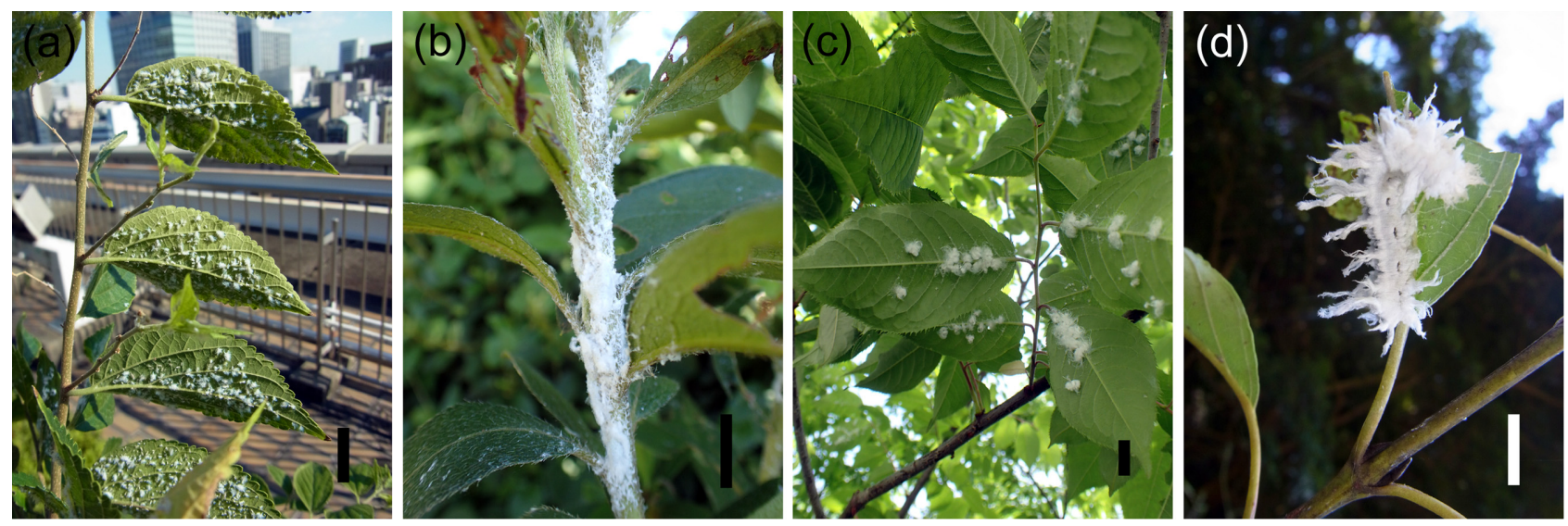

Fig. 2. Wax-producing insects. (a) Shivaphis celti, (b) Geisha distinctissima, (c) Psylla morimotoi, (d) Epicopeia hainesii hainesii. Scale bars: $10 \mathrm{~mm}$.

bacher spp.), on various plant taxa (Table 1b). These waxproducing insects occurred intermittently from spring to autumn commonly in lowland and mountainous areas, and were found on buds (C. yasushii), stems (C. clematis, lepidopteran caterpillars) or the undersides of leaves ( $S$. celti, A. mori, P. morimotoi, Eriocampa spp., E. hainesii hainesii). White colonies of woolly aphids and jumping plant lice on the underside of leaves looked like trichome-covered leaves (Fig. 2a). Stems covered with wax-producing flatid nymphs, which resembled white plant stems, were abundant in spring and early summer (Fig. 2b).
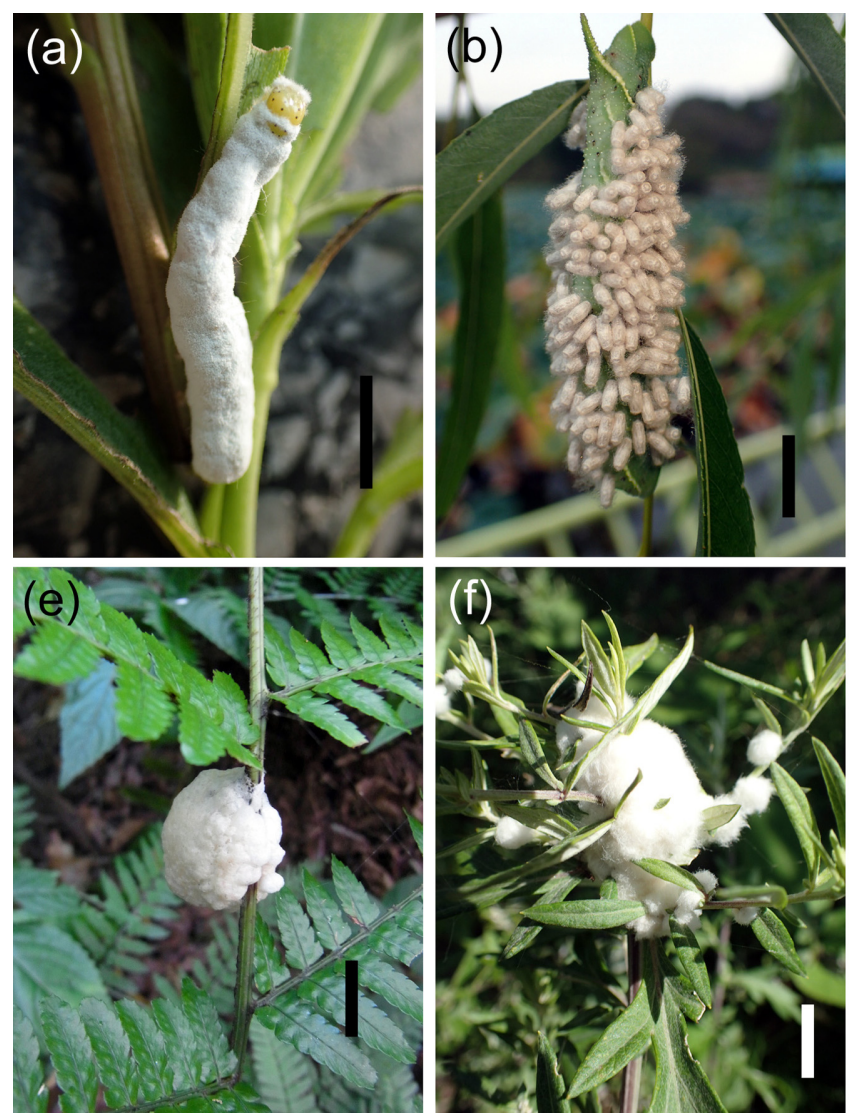

\section{Other white structures produced by insects and plants}

Furthermore, fungus-infected insects [e.g. caterpillars (Fig. 3a), cicadas] covered with white fungal hyphae and conidia, were found in rainy summers and autumns and were visually similar to wax-producing caterpillars or homopteran colonies. Other structures made by various terrestrial arthropods resemble wax-producing insects or white plant structures: gregarious braconid cocoons (Fig. 3b), spider egg sacs and webs (Fig. 3c), froth made by froghopper nymphs (Fig. 3d) or blasticotomid sawfly

Fig. 3. White structures produced by arthropods and plants. (a) Ctenoplusia albostriata (Bremer \& Grey) caterpillar infected with entomopathogenic fungi, (b) braconid cocoons on Smerinthus planus Walker caterpillar, (c) web of a dictynid spider, (d) spittlebug froth, (e) blasticotomid froth, (f) Rhopalomyia giraldii gall, (g) Sonchus oleraceus pappi, (h) Salix bakko comae. Scale bars: 10 mm. 
larvae (Fig. 3e) and cotton-like galls induced by the gall midge Rhopalomyia giraldii Kieffer \& Trotter (Fig. 3f). These white structures were commonly found from spring to autumn in lowland to mountainous areas (Table 1c). Other plant parts, including asteraceous pappi (Fig. 3g) and salicaceous comae (Fig. 3h), also look like wax-producing insect colonies (Table 1c), but such plant structures were seen only during a limited period in spring.

\section{HYPOTHESES}

\section{White shoots may mimic wax-producing insects}

White plant shoots and wax-producing insects are visually similar (i.e., cylindrical, sheet like or patchy in appearance) and can be commonly found from spring to autumn and in both lowlands and mountainous regions (Table 1). Therefore, I propose that white young shoots may visually mimic wax-producing insects, potentially leading to a decrease in herbivory for the following reasons.

It is very important for plants to protect their young shoots, as they contain soft, nutritious meristems and growing tissues that are essential for vegetative growth and reproduction, and they are thus more vulnerable to herbivory than older shoots. Although mature plant tissues are sometimes also attacked by herbivores, physical toughness and chemical defences generally make them less vulnerable to herbivory (e.g., Feeny, 1970; Lev-Yadun $\&$ Ne'eman, 2007). Young shoots covered with white trichomes and waxy substances are found coincidentally with wax-producing insects at a variety of sites and in different seasons. This white colouration is visually striking against dark backgrounds (Lev-Yadun, 2014b). Wax-producing herbivorous insects reduce food plant quality or quantity by sucking plant sap, consuming leaves and transmitting pathogens (Eastop, 1977). Wax or wax-producing insects are distasteful or a deterrent to many other arthropods, including ants and spiders, and possibly also to vertebrates (Eisner et al., 2005; Moss et al., 2006; Schwartzberg et al., 2010; Yamazaki, 2012). Although a waxy cover deters predation by ants and spiders, certain wax-producing homopterans are tended by ants and attacked by predators and parasitoids (Delabie, 2001; Eisner et al., 2005), rendering shoots with wax-producing insects dangerous or less palatable to other herbivores.

Based on these facts and observations, such white-coloured shoots are proposed here to visually mimic waxproducing insects, resulting in reduced herbivory. Simultaneously, white coatings on new shoots may mimic phytopathogenic fungal infections (Lev-Yadun, 2006b, 2016; Yamazaki \& Lev-Yadun, 2015) or wounded shoots oozing white toxic latex (Lev-Yadun, 2014b) and in addition, probably protect plant tissues from UV light and desiccation (Lee, 2007), as well as from attack by herbivorous insects (Levin, 1973).

\section{White mimicry complex across plants, fungi and arthropods}

Moreover, other white structures produced by arthropods, including fungal-infected insects (though their white colour is derived from fungal hyphae and spores), parasitoid cocoons, spider egg sacs and webs, froghopper froth and some plant galls that resemble wax-producing insects and each other, can be found in various habitats throughout the vegetative season (Table 1). Thus, Müllerian and Batesian white mimicry complexes and rings may extend beyond young white shoots mimicking wax-producing insects.

White structures other than wax produced by arthropods are harmful to herbivores. For example, fungal-infected insects are lethal for other herbivorous insects because of the possibility of horizontal transmission, and because they may contain toxic substances (Roy et al., 2006). Froth produced by spittlebugs and blasticotomid sawflies contains a detergent (Mello et al., 1987; Cooper \& Kennedy, 2010) and small arthropods may drown in the foam. Because spider egg sacs and webs indicate the presence of mature spiders, herbivores are likely to avoid them, as suggested by recent studies of non-consumptive negative effects of spiders on herbivores (Hlivko \& Rypstra, 2003; Rypstra \& Buddle, 2013; Yamazaki \& Lev-Yadun, 2015). Parasitoid cocoons indicate that parasitoids are present in the vicinity. Owing to their conspicuous white colour, these structures, as well as wax produced by arthropods, may provide herbivores with obvious cues of hazards. Consequently, they may function in a manner similar to Müllerian mimicry, if several such taxa occur together.

It is also possible and probable that these white arthropod structures have simultaneous physical and physiological functions, and that they only secondarily serve as a defensive mimicry complex. Parasitoid cocoons, spider egg sacs and froghoppers are in fact attacked by specialist predators and parasitoids (Tagawa \& Fukushima, 1993; Sullivan \& Völkl, 1999; Finch, 2005; Tanaka \& Ohsaki, 2006); however, many generalist predators and parasitoids may find it difficult to handle wax, cocoons, egg sacs and froth (Whittaker, 1970; Austin, 1985; Akiyama \& Matsumoto, 1986; Hieber, 1992; Eisner et al., 2005). White cotton-like galls may mimic these white arthropod structures and reduce herbivory on galls and surrounding plant tissues, resulting in higher survival rates for galling insects and their host plants. Because galls are attractive food sources for certain herbivores they are vulnerable to herbivory if not well-defended and as a consequence may be protected by aposematism and mimicry in addition to chemical and physical defences (Inbar et al., 2010; Rostás et al., 2013; Yamazaki, 2016). Plant pappi and comae are white and abundant, but also temporal. Therefore, these plant structures do not seem to be an important part of the white mimicry complex.

\section{DISCUSSION}

Some insects, such as lacewing larvae, use homopteran wax to cover their bodies in order to deter predators and parasitoids (Eisner et al., 1978; Eisner \& Silberglied, 1988; Mason \& Fales, 1991). Possible instances of defensive Batesian or Müllerian mimicry among wax-producing insects are also known (Pope, 1979; Yamazaki, 2012). Plant 
mimicry of arthropods to deter herbivory may be widespread, much like predator-deterring mimicry among insects (Lev-Yadun \& Inbar, 2002; Lev-Yadun, 2016, 2017). In particular, it is plausible that young shoots, bearing white trichomes or waxy substances, reduce herbivory by creating a visual resemblance to wax-producing insects.

To investigate this mimicry hypothesis further, the optical characteristics (e.g. under both visible and UV spectra) of white shoots and insect-produced wax should be compared. Future studies should also investigate the effects on herbivory of removing white trichomes or waxy substances from shoots, or adding white coatings to normal shoots. Furthermore, herbivore damage, and rates of visitation by predators and parasitoids should be compared between related plants bearing normal shoots versus white shoots. Patterns in the occurrence of such white structures should be examined in relation to the intensity of herbivory using phylogenetically controlled methods.

In conclusion, because white is a prominent colour in forests and grasslands, white structures often serve as warning signals. In some plant species, young shoots may mimic wax-producing insects, probably leading to reduced herbivory. In addition, fungus-infected insects, spider egg sacs, parasitoid cocoons and froghopper froth are also likely to be mimicry models for white shoots, and together constitute a white mimicry complex along with wax-producing insects. Further observations on other organisms using optical analyses and field experiments are required to confirm the existence and elucidate the mechanisms of this putative defensive mimicry complex.

ACKNOWLEDGEMENTS. I thank two associate editors, S. LevYadun and anonymous reviewers for constructive comments for improving this manuscript. This research was supported by JSPS KAKENHI Grant Number JP17K07869.

\section{REFERENCES}

Aкiуama M. \& Matsumoto K. 1986: Biology of the pine spittlebug, Aphrophora flavipes (Homoptera: Cercopidae) in the nymphal stage. - Jpn. J. Appl. Entomol. Zool. 30: 136-141.

Allaby M. 2010: A Dictionary of Ecology. Oxford University Press, Oxford, 418 pp.

Austin A.D. 1985: The function of spider egg sacs in relation to parasitoids and predators, with special reference to the Australian fauna. - J. Nat. Hist. 19: 359-376.

BRown K.S. 1975: The chemistry of aphids and scale insects. Chem. Soc. Rev. 4: 263-288.

CARo T. 2005: The adaptive significance of coloration in mammals. - BioScience 55: 125-136.

CARo T. 2009: Contrasting coloration in terrestrial mammals. Phil. Trans. R. Soc. (B) 364: 537-548.

Cloudsley-Thompson J.L. 1979: Adaptive functions of the colours of desert animals. - J. Arid Environ. 2: 95-104.

Cooper A. \& KenNedy M.W. 2010: Biofoams and natural protein surfactants. - Biophys. Chem. 151: 96-104.

Сотт H.B. 1940: Adaptive Coloration in Animals. Methuen, London, $540 \mathrm{pp}$.

Delabie J.H.C. 2001: Trophobiosis between Formicidae and Hemiptera (Sternorrhyncha and Auchenorrhyncha): an overview. — Neotrop. Entomol. 30: 501-516.
EASTOP V.F. 1977: Worldwide importance of aphids as virus vectors. In Harris K.F. \& Maramorosch K. (eds): Aphids as Virus Vectors. Academic Press, New York, pp. 3-62.

Edmunds M. 1974: Defence in Animals: A Survey of Anti-Predator Defences. Longman, Harlow, 357 pp.

EISNER T. \& SiLBeRglied R.E. 1988: A chrysopid larva that cloaks itself in mealybug wax. - Psyche 95: 15-19.

Eisner T., Silberglied R.E., Aneshansley D., Carrel J.E. \& Howland H.C. 1969: Ultraviolet video-viewing: the television camera as an insect eye. - Science 166: 1172-1174.

Eisner T., Hicks K., Eisner M. \& Robson D.S. 1978: "Wolf-insheep's-clothing" strategy of a predaceous insect larva. - Science 199: 790-794.

Eisner T., Eisner M. \& Siegler M. 2005: Secret Weapons: Defenses of Insects, Spiders, and Other Many-Legged Creatures. Belknap, Harvard, Cambridge, MA, 384 pp.

FEENY O. 1970: Seasonal changes in oak leaf tannins and nutrients as a cause of spring feeding by winter moth caterpillars. - Ecology 51: 565-581.

FinCH O.-D. 2005: The parasitoid complex and parasitoid-induced mortality of spiders (Araneae) in a Central European woodland. - J. Nat. Hist. 39: 2339-2354.

Hieber C.S. 1992: Spider cocoons and their suspension systems as barriers to generalist and specialist predators. - Oecologia 91: $530-535$.

Hilker M. \& Meiners T. 2011: Plants and insect eggs: how do they affect each other? - Phytochemistry 72: 1612-1623.

HLIVKo J.T. \& RYPSTRA A.L. 2003: Spiders reduce herbivory: nonlethal effects of spiders on the consumption of soybean leaves by beetle pests. - Ann. Entomol. Soc. Am. 96: 914-919.

Howse P. 2014: Seeing Butterflies: New Perspectives on Colour, Patterns \& Mimicry. Papadakis, Berkshire, 176 pp.

Inbar M., Izhaki I., Koplovich A., Lupo I., Silanikove N., Glasser T., Gerchman Y., Oerevolotsky A. \& Lev-Yadun S. 2010: Why do many galls have conspicuous colors? A new hypothesis. - Arthrop. Plant Interact. 4: 1-6.

Karban R. 2015: Plant Sensing and Communication. University Chicago Press, Chicago, 240 pp.

Karban R. \& Baldwin I.T. 1997: Induced Responses to Herbivory. University Chicago Press, Chicago, 319 pp.

Kessler A. \& BaLdwin I.T. 2001: Defensive function of herbivore induced plant volatile emissions in nature. - Science 291: 2141-2144.

LeE D. 2007: Nature's Palette: The Science of Plant Color. University Chicago Press, Chicago, $409 \mathrm{pp}$.

LEvin D.A. 1973: The role of trichomes in plant defense. $-Q$. Rev. Biol. 48: 3-15.

LEV-YADUN S. 2006a: Defensive coloration in plants: a review of current ideas about anti-herbivore coloration strategies. In Teixeira da Silva J.A. (ed.): Floriculture, Ornamental and Plant Biotechnology: Advances and Topical Issues. Vol. IV. Global Science Books, London, pp. 292-299.

LEV-YADUN S. 2006b: Defensive functions of white coloration in coastal and dune plants. - Isr. J. Plant Sci. 54: 317-325.

LEV-YADUN S. 2014a: The proposed anti-herbivory roles of white leaf variegation. - Prog. Bot. 76: 241-269.

LEV-YADUN S. 2014b: Why is latex usually white and only sometimes yellow, orange or red? Simultaneous visual and chemical plant defense. - Chemoecology 24: 215-218.

Lev-Yadun S. 2016: Defensive (Anti-herbivory) Coloration in Land Plants. Springer, Zug, 385 pp.

LeV-YADUN S. 2017: Defensive animal and animal-action mimicry by plants. - Isr. J. Plant Sci. 64: [in press].

Lev-Yadun S. \& Inbar M. 2002: Defensive ant, aphid and caterpillar mimicry in plants. - Biol. J. Linn. Soc. 77: 393-398. 
Lev-Yadun S. \& Ne'eman G. 2007: Color changes in old aposematic thorns, spines, and prickles. - Isr. J. Plant Sci. 54: 327-333.

Lev-Yadun S. \& Ne'eman G. 2012: Does bee or wasp mimicry by orchid flowers also deter herbivores? - Arthrop. Plant Interact. 6: 327-332.

LEV-YADUN S. \& Niemelä P. 2017: Leaf-pseudo-variegation: Definition, common types, and probably the defended models for defensive leaf variegation mimicking them? - Flora 226: $82-88$.

Mason R.T. \& Fales H.M. 1991: Wax of a whitefly and its utilization by a chrysopid larva. - Naturwissenschaften 78: 28-30.

Mello M.L.S., Pimentel E.R., Yamada A.T. \& Storopolineto A. 1987: Composition and structure of the froth of the spittlebug, Deois sp. - Insect Biochem. 17: 493-502.

Moss R., Jackson R.R. \& Pollard S.D. 2006: Mask of wax: secretions of wax conceal aphids from detection by spider's eyes. - N. Z. J. Zool. 33: 215-220

Niemelä P. \& TuOMI J. 1987: Does the leaf morphology of some plants mimic caterpillar damage? - Oikos 50: 256-257.

Polidori C., Nieves-Aldrey J.L., Gilbert F. \& Rotheray G.E. 2014: Hidden in taxonomy: Batesian mimicry by a syrphid fly towards a Patagonian bumblebee. — Insect Conserv. Divers. 7: $32-40$.

Polte S. \& Reinhold K. 2013: The function of the wild carrot's dark central floret: attract, guide or deter? - Plant Spec. Biol. 28: $81-86$.

Pope R.D. 1979: Wax production by coccinellid larvae (Coleoptera). - Syst. Entomol. 4: 171-196.

Pope R.D. 1983: Some aphid waxes, their form and function (Homoptera: Aphididae). — J. Nat. Hist. 17: 489-506.

Rostás M., MAag D., IKegami M. \& InBar M. 2013: Gall volatiles defend aphids against a browsing mammal. - BMC Evol. Biol. 13: $193,11 \mathrm{pp}$.

Roy H.E., Steinkraus D.C., Eilenberg J., Hajek A.E. \& Pell J.K. 2006: Bizarre interactions and endgames: entomopathogenic fungi and their arthropod hosts. - Annu. Rev. Entomol. 51: 331-357.

Ruxton G.D., Sherratt T.N. \& Speed M.P. 2004: Avoiding Attack: The Evolutionary Ecology of Crypsis, Warning Signals and Mimicry. Oxford University Press, Oxford, 249 pp.

Rypstra A.L. \& Buddle C.M. 2013: Spider silk reduces insect herbivory. - Biol. Lett. 9: 20120948, 4 pp.

Schwartzberg E.G., Haynes K.F., Johnson D.W. \& Brown G.C. 2010: Wax structures of Scymnus louisianae attenuate aggression form aphid-tending ants. — Environ. Entomol. 39: 13091314.
SKelhorn J. 2015: Masquerade. - Curr. Biol. 25: R643-R644.

Skelhorn J., Rowland H.M., SpeEd M.P. \& Ruxton G.D. 2010: Masquerade: camouflage without crypsis. - Science 327: 51.

Soltau U., Dötterl S. \& Liede-Schumann S. 2009: Leaf variegation in Caladium steudneriifolium (Araceae): a case of mimicry? - Evol. Ecol. 23: 503-512.

SUlLIVAN D.J. \& VölKL W. 1999: Hyperparasitism: multitrophic ecology and parasitism. - Annu. Rev. Entomol. 44: 291-315.

SuZUKi T.N. \& SAKURAI R. 2015: Bent posture improves the protective value of bird dropping masquerading by caterpillars. Anim. Behav. 105: 79-84.

TAGaWA J. \& FuKushima H. 1993: Effects of host age and cocoon position on attack rate by the hyperparasitoid, Eurytoma $\mathrm{sp}$. (Hym.: Eurytomidae), on cocoons of the parasitoid, Cotesia (= Apanteles) glomerata (Hym.: Braconidae). - Entomophaga 38: 69-77.

TANAKA H. 1982: Relationship between ultraviolet and visual spectral guidemarks of 93 flowers and the pollinators. $-J$. Jap. Bot. 57: 146-159.

TANAKA S. \& OHSAKI N. 2006: Behavioral manipulation of host caterpillars by the primary parasitoid wasp Cotesia glomerata (L.) to construct defensive webs against hyperparasitism. Ecol. Res. 21: 570-577.

WhitTAKer J.B. 1970: Cercopid spittle as a microhabitat. Oikos 21: 59-64.

WICKLER W. 1968: Mimicry in Plants and Animals. Weidenfeld and Nicholson, London, 253 pp.

Williams K.S. \& Gilbert L.E. 1981: Insects as selective agents on plant vegetative morphology: Egg mimicry reduces egg laying by butterflies. - Science 212: 467-469.

YAMAZAKI K. 2012: A possible collective mimicry of waxy caterpillars, Epicopeia hainesii hainesii Holland 1889 (Lepidoptera: Epicopeiidae), by woolly aphids, Colophina clematis (Shinji 1922) (Hemiptera: Aphididae). — Pan-Pac. Entomol. 88: 431-434.

YAMAZAKI K. 2016: Caterpillar mimicry by plant galls as a visual defense against herbivores. - J. Theor. Biol. 404: 10-14.

YAMAZAKI K. \& LeV-Yadun S. 2014: Dark axils and nodes in various plant species may serve as defensive mimicry of beetles and beetle feces. - J. Nat. Hist. 48: 691-698.

YAMAZAKI K. \& Lev-Yadun S. 2015: Dense white trichome production by plants as possible mimicry of arthropod silk or fungal hyphae that deter herbivory. - J. Theor. Biol. 364: 1-6.

Received March 3, 2017; revised and accepted June 29, 2017 Published online July 26, 2017 